\title{
PENGARUH BERMAIN SOLITARY PLAY TERHADAP PROSES PENYEMBUHAN ANAK USIA 2-3 TAHUN DENGAN FEBRIS DHF DI BANGSAL TERATAI RUMAH SAKIT DR. OEN SURAKARTA
}

\author{
Oleh : \\ Rahayu Setyaningsih ${ }^{1}$ Endang Dwi Ningsih ${ }^{2}$
}

\begin{abstract}
Background Playing is an activity that can be done as an effort to stimulate the child's growth and development. Playing for the children at hospital can be a medium to express feelings of relaxation and distract of discomfort due to illness.

The purpose of this study was determine the effect of playing therapy with solitary paly on healing process of children aged 2-3 years with Dengue Hemorragic Fever who hospitalized at Teratai ward of Dr.Oen Surakarta.

Methods This study used a pre-experiment design with one shot case study approach. The playing therapy was done in 8 patients consisted 3 boys and 5 girls. Data were collected using an observation sheet. Data processing used ttest statistical test with significance level $\alpha: 0.05$.

The conclusion The result showed $t$ count $>t$ table $(2.379>2.365)$. It can be concluded that solitary play therapy gave significant effect fever at Teratai of Dr.Oen Surakarta hospital.
\end{abstract}

Keywords : Play Therapy, Healing Process

\section{PENDAHULUAN}

Bermain merupakan aktivitas yang dapat dilakukan anak sebagai upaya stimulasi pertumbuhan dan perkembangannya dan bermain pada anak dirumah sakit dapat menjadi media bagi anak untuk mengekspresikan perasaan relaksasi dan distraksi perasaan yang tidak nyaman. (Supartini, 2004) Menurut Chusairi (2006), penelitian yang dilakukan untuk membuktikan efektivitas pengaruh terapi bermain sosial terhadap peningkatan kemampuan dan keterampilan sosial pada anak dengan gangguan autisme. Hasil penelitian menunjukkan bahwa terdapat pengaruh yang signifikan dari terapi bermain sosial terhadap peningkatan kemampuan dan keterampilan anak dengan gangguan autisme.

Disamping itu telah diketahui bahwa sejak Januari sampai dengan 5 Maret tahun 2004 total kasus DBD diseluruh provinsi di Indonesia sudah mencapai 26.015, dengan jumlah kematian sebanyak 389 orang ( CFR $=1,53 \%$ ).

Penyakit demam berdarah atau Dengue Hemorrhagic Fever (DHF) ialah penyakit yang disebabkan oleh virus dengue yang ditularkan melalui gigitan nyamuk Aedes Aegypti dan Aedes Albopictus. Kedua jenis nyamuk ini terdapat hampir diseluruh pelosok Indonesia, kecuali ditempattempat ketinggian lebih dari 1.000 meter di atas permukaan air laut. Data di bagian anak RSCM menunjukkan pasien DBD sering menunjukkan gejala batuk, pilek, muntah, mual, maupun diare. (Kristina, 2007)

Dari hasil observasi dan wawancara terhadap perawat yang bertugas yang dilakukan oleh peneliti di Bangsal Teratai RS dr. Oen Surakarta sejumlah 35 anak terdapat kurang lebih $75 \%$ anak cenderung 
sulit diberikan terapi oleh tim medis karena sakit yang dirasakannya. Dari uraian di atas peneliti tertarik untuk melakukan penelitian lebih lanjut mengenai pengaruh terapi bermain solitary play terhadap proses penyembuhan anak usia 2-3 tahun dengan febris DHF di bangsal Teratai rumah sakit $d r$. Oen Surakarta.

\section{METODE PENELITIAN}

Penelitian ini merupakan penelitian yang menggunakan rancangan penelitian pre eksperimental dengan pendekatan one shot case study. Rancangan pre eksperimental adalah rancangan yang berupaya untuk mengungkapkan hubungan sebab akibat dengan cara melibatkan kelompok kontrol disamping kelompok eksperimental. (Nursalam dan Pariani, 2000)

One shot case study adalah cara penelitian pre eksperimental design dengan memberikan perlakuan kemudian dilihat dampaknya atau pengaruhnya. (Hidayat, 2003)

\section{HASIL PENELITIAN}

Berdasarkan penelitian yang telah dilakukan pada anak usia 2-3 tahun yang sakit Febris DHF dapat diuraikan sebagai berikut :

Tabel 1. Karakteristik Responden Bersadarkan Jenis Kelamin

\begin{tabular}{ccc}
\hline Kategori & $\mathrm{F}$ & $\%$ \\
\hline Laki-laki & 3 & 37,5 \\
Perempuan & 5 & 62,5 \\
\hline Jumlah & 8 & 100 \\
\hline
\end{tabular}

Dari data di atas menunjukkan bahwa sebagian responden berjenis kelamin perempuan (62,50\%), sedangkan yang paling sedikit berjenis kelamin laki-laki (37, 50\%).
Tabel 2. Karakteristik Responden Bersadarkan Kelompok Umur

\begin{tabular}{ccc}
\hline Kategori & $F$ & $\%$ \\
\hline $25-29$ & 3 & 37,5 \\
$30-34$ & 1 & 12,5 \\
$35-39$ & 2 & 25,00 \\
$40-44$ & 0 & 0 \\
$45-49$ & 2 & 25,00 \\
\hline Jumlah & 8 & 100 \\
\hline
\end{tabular}

Dari data di atas menunjukkan bahwa sebagian besar responden berada pada kelompok umur 25-29 tahun yaitu sebesar $37,50 \%$ sedangkan yang paling sedikit pada kelompok umur 30-34 tahun yaitu sebesar $12,5 \%$.

Tabel 3. Karakteristik Responden Berdasarkan Pekerjaan

\begin{tabular}{ccc}
\hline Kategori & $\mathrm{F}$ & $\%$ \\
\hline Wiraswasta & 3 & 37,5 \\
Sipil/PNS & 2 & 25,00 \\
Pengangguran & 3 & 37,50 \\
\hline Jumlah & 8 & 100 \\
\hline
\end{tabular}

Dari data di atas menunjukkan bahwa sebagian besar responden memiliki pekerjaan sebagai wiraswasta dan pengangguran sebesar $37,50 \%$ dan pegawai sipil atau PNS sebesar $25 \%$.

Tabel 4. Tabulasi Silang Pengaruh Terapi Bermain terhadap Proses Penyembuhan Febris DHF pada Anak Usia 2-3 Tahun.

\begin{tabular}{cccc}
\hline $\begin{array}{c}\text { Hasil } \\
\text { Pre } \\
\text { Test }\end{array}$ & $\begin{array}{c}\text { Hasil } \\
\text { Post } \\
\text { Test }\end{array}$ & $\begin{array}{c}\text { Selisih } \\
\text { hasil (d) }\end{array}$ & $\mathbf{d}^{2}$ \\
\hline 16 & 17 & 1 & 1 \\
\hline 16 & 18 & 2 & 4 \\
\hline 16 & 17 & 1 & 1 \\
\hline 19 & 18 & 1 & 1 \\
\hline 14 & 16 & 2 & 4 \\
\hline 20 & 20 & 0 & 0 \\
\hline 17 & 20 & 3 & 9 \\
\hline 9 & 18 & 9 & 81 \\
\hline 127 & 144 & 19 & 101 \\
\hline
\end{tabular}


Berdasarkan tabel di atas, dapat diketahui bahwa hasil total nilai post test (144) lebih tinggi dari pada nilai total pre test (127).

Setelah dilakukan penghitungan dengan uji statistik menggunakan paired t test dengan taraf signifikasi atau tingkat kemaknaan atau alpha sebesar $5 \%(0,05)$ didapatkan nilai $t$ hitung $>$ t tabel $(2,379>2,365)$ yang berarti Ho ditolak dan Ha diterima. Dengan demikian nilai tersebut menunjukkan bahwa ada pengaruh yang bermakna antara terapi bermain solitary play terhadap proses penyembuhan anak usia 2-3 tahun dengan Febris DHF di bangsal Teratai RS. Dr. Oen Surakarta.

\section{PEMBAHASAN}

Hasil uji korelasi dari analisa statistik menggunakan paired $t$ test mengenai pengaruh terapi bermain solitary play terhadap proses penyembuhan DHF yaitu sebesar 2,379 . Hal ini menunjukkan bahwa ada pengaruh terapi bermain solitary play terhadap proses penyembuhan DHF pada anak usia 2-3 tahun. Data diambil dari 8 responden berdasarkan jawaban kuesioner yang pada pelaksanaannya sebagian diberikan terapi bermain dan jumlah yang sebagian lagi tidak diberikan terapi bermain.

Hasil penelitian dari pengaruh terapi bermain solitary play terhadap proses penyembuhan DHF mempunyai nilai tertinggi pada post test (144) dibanding nilai pre test (110). Penelitian pengaruh terapi bermain menggunakan pedoman terapi bermain solitary play menurut Supartini (2004), dimana anak pada usia toddler ( $>1$ tahun) sampai 3 tahun) bermain sendiri dengan alat permainan yang dimilikinya meski tampak dalam kelompok, tidak ada kerja sama ataupun komunikasi dengan teman sepermainannya serta anak banyak gerak, tidak bisa diam mempunyai rasa ingin tahu yang besar dan mulai mengembangkan otonomi dan kemampuannya untuk dapat mandiri. Selain itu permainan merupakan media komunikasi antara anak dengan orang lain, termasuk dengan perawat atau petugas kesehatan dirumah sakit. Hal ini dikarenakan saat anak dirawat dirumah sakit anak akan menghadapi stresor yang ada dilingkungan rumah sakit.

Hasil penelitian dari proses penyembuhan febris DHF responden, didapatkan bahwa sebagian besar responden tidak sembuh (62,5\%). Penelitian proses penyembuhan responden menggunakan pedoman teknik klasifikasi derajat penyakit infeksi virus dengue menurut FKUI (2006) dimana gejala penyakit DHF yang ada mulai berkurang dan akhirnya hilang. Namun dari hasil penelitian ini dapat disimpulkan bahwa ada pengaruh terapi bermain solitary play terhadap proses penyembuhan anak usia 2-3 tahun dengan Febris DHF di Bangsal Teratai Rumah Sakit Dr. Oen Surakarta dengan hasil $t$ hitung $>t$ tabel $(2,379>2,365)$ yang berarti Ho ditolak dan $\mathrm{Ha}$ diterima. Hal ini berdasarkan pada pendapat maupun pandangan dari orangtua terhadap pemberian terapi bermain yang diperlakukan ke anak mereka. Dilihat dari perubahan sikap anak yang semula takut dan menolak terhadap perlakuan dari tim medis, namun dengan diberikannya terapi bermain, anak menjadi tidak takut, sebagaimana menurut Wong (2003) bahwa terapi bermain yang dilakukan pada anak baik sebelum maupun saat melakukan prosedur dapat mengurangi rasa tegang, takut dan emosi yang dirasakan anak selama prosedur dijalankan. Dengan demikian anak menjadi lebih menerima tindakan prosedur yang ada dan anak memperoleh pengobatan yang dapat membantu proses penyembuhan sakitnya. Dimana dalam penelitian ini, 
terdapat lebih banyak anak yang masih dalam tahap awal mendapatkan sakit febris DHF sehingga belum dapat dilihat perkembangannya dalam hal peningkatan proses penyembuhan secara baik.

\section{KESIMPULAN DAN SARAN}

1. Kesimpulan

a. Dari 8 responden, diperoleh data bahwa sebagian besar responden berjenis kelamin perempuan $(62,50 \%)$, sedangkan yang paling sedikit berjenis kelamin lakilaki $(37,50 \%)$ dengan 37,50 $\%$ responden berada pada kelmpok umur 25-29 tahun dan $12,5 \%$ pada kelompok umur 30-34 tahun.

b. Sebagian besar responden memiliki pekerjaan sebagai wiraswasta dan pengangguran sebesar $37,50 \%$ dan sebagai pegawai sipil atau PNS sebesar $25 \%$.

c. Ada pengaruh terapi bermain solitary play terhadap proses penyembuhan anak usia 2-3 tahun dengan febris DHF di Bangsal Teratai RS. Dr. Oen Surakarta.

2. Saran

a. Bagi Instansi Rumah Sakit Instansi Rumah Sakit diharapkan lebih berperan aktif dalam pemberian terapi bermain pada anak-anak yang dirawat di Bangsal Teratai melalui perawatperawat yang memberikan asuhan keperawatan.

b. Bagi orangtua

Diharapkan dalam penelitian ini orang tua lebih berperan aktif dan dapat memberi dukungan yang positif terhadap anak-anak mereka yang sedang dirawat di bangsal Teratai RS. Dr. Oen Surakarta. c. Bagi peneliti

Diharapkan untuk penelitian selanjutnya, peneliti dapat melakukan penelitian yang lebih spesifik misalnya pengaruh terapi bermain terhadap penurunan stres anak yang dirawat di RS.

\section{DAFTAR PUSTAKA}

Hidayat, Aziz A. Riset Keperawatan \& Teknik Penulisan IImiah. Jakarta : Salemba Medika, 2003.

Budiarto, Eko. Biostatistik Untuk Kedokteran dan Kesehatan Masyarakat. Jakarta : EGC, 2001.

Nursalam \& Siti Pariani. Pendekatan Praktis Metodologi Riset Keperawatan. Jakarta : CV. Sagung Seto, 2001.

Riwidikdo, Handoko. Statistik Kesehatan : Belajar Mudah Teknik Analisis Data Dalam Penelitian Kesehatan (Plus Aplikasi Software SPSS). Yogyakarta : Mitra Cendikia Press, 2007.

Sudoyo, Aru W, et al., ed. Buku Ajar IImu Penyakit Dalam. Jakarta : FKUI, 2006.

Sugiyono. Statistika untuk Penelitian. Bandung : CV. Alfabeta, 2005.

Suherman. Buku Saku Perkembangan Anak. Jakarta : EGC, 2000.

Supartini, Yupi. Buku Ajar Konsep Dasar Keperawatan Anak. Jakarta : EGC, 2004.

Wahap, A. Samik, et al., ed. IImu Kesehatan Anak Nelson. Volume 1. Edisi 15. Jakarta : EGC, 2000. 
Wong , Donna L. Pedoman Klinis Keperawatan Pediatrik. Jakarta : EGC, 2003.

World Health Organization. Pencegahan dan Pengendalian Dengue dan Demam Berdarah Dengue : Panduan Lengkap. Alih bahasa, Palupi Wadyastuti. Jakarta : EGC, 2004.

Chusairi, Hamidah, Tino Leonardi. Efektiviitas Pengaruh Terapi Bermain Sosial Terhadap Peningkatan Kemampuan Dan Ketrampilan Sosial Pada Anak Dengan Autism. Universitas Airlangga, 2006

1 Dosen AKPER Panti Kosala

Surakarta

2 Dosen AKPER Panti Kosala Surakarta 